\title{
PENGARUH KUALITAS LAYANAN TERHADAP LOYALITAS KONSUMEN STUDI KASUS: BELANJA ONLINE BHINNEKA.COM
}

\author{
Michael Christian ${ }^{1}$, Vincent Nuari $^{2}$ \\ Universitas Bunda Mulia Jakarta \\ e-mail: lect1025@yahoo.com \\ e-mail: Vincent.nuari@gmail.com
}

\begin{abstract}
This research aims to identify the effect of E-Service Quality towards to E-Loyalty. By using the website of Bhineka.com and 219 respondentswho had online shopping experienced at this website, this research shows that E-Service Quality on Bhineka.com has effected significantly positive towards to E-Service Quality. The result of this study shows that variable of e-servicequality dan overall e-service quality influence to e-satisfaction. Thus, e-satisfaction become important variable that influence e-loyalty because e-satisfaction gives positif effect to loyalty.
\end{abstract}

Keywords: E-Service Quality, Overall E-Service Quality, E-Satisfaction, E-Loyalty, E-Commerce, Bhinneka.com

http://dx.doi.org/10.20885/jsb.vol20.iss1.art4

\begin{abstract}
Abstrak
Penelitian ini dilakukan untuk mengetahui apakah terdapat pengaruh antara kualitas layanan secara elektronik terhadap loyalitaskonsumen dalam studi kasus situs Bhinneka.com. Responden pada penelitian ini adalah konsumen yang sudah pernah melakukan transaksi pembelian secara online dari website Bhinneka.com.Teknik pengumpulan data yang digunakan adalah dengan penyebaran kuesioner online yang terdiri dari 40 indikator pertanyaan dimana menggunakan skala Likert 1-7. Jumlah responden yang digunakan sebanyak 219 responden. Dengan menggunakan program Smart PLS2.0 M3, hasil dari penelitian ini menunjukkan pengaruh secara signifikan positif terhadapELoyalty Hasil penelitian ini menunjukkan hasil bahwa e-service quality dan overall e-service quality memiliki pengaruh pada $e$-satisfaction. Sedangkan $e$-satisfaction menjadi variable penting dalam mempengaruhi $e$-loyalty.
\end{abstract}

Kata Kunci: Kualitas Layanan Elektronik, Loyalitas Pelanggan, Kepuasan Pelanggan, Bhineka.com

\section{PENDAHULUAN}

\section{Latar Belakang}

Kemajuan teknologi informasi membuat internet saat ini semakin menjadi hal yang tidak terpisahkan dari kehidupan manusia di era modern. Data yang diambil dari internetworldstats.com (2014) menunjukan bahwa jumlah pengguna internet di Indonesia saat ini berkisar 71.190.000 yang tersebar di 34 propinsi di Indonesia. Dalam situs tersebut disebutkan bahwa Indonesia menempati peringkat ke empat sebagai pengguna internet terbanyak untuk kawasan Asia. Berdasarkan data tersebut, maka, dapat disimpulkan bahwa masyarakat Indonesia sudah sadlar akan internet.
Asosiasi Penyelenggara Jasa Internet Indonesia (APJII) pada tahun 2012 mempublikasikan data bahwa media akses penggunan internet didominiasi oleh Smartphone 96,9\%, telepon kabel $85 \%$, jaringan nirkabel (Wi-Fi) $49 \%$ dan sisanya TV kabel dan satelit masing masing $11,4 \%$ dan 3,4\% (Gambar 1). Data tersebut juga menyebutkan bahwa mayoritas intensitas akses internet (Gambar 2) adalah sosial media $87,8 \%$, pencarian informasi (browsing) 68,9\% dan yang paling minim adalah perdagangan online yang hanya sebesar $0,1 \%$ saja. Ini disebabkan oleh sebagian besar pengguna internet yang belum memanfaatkan fasilitas jual beli secara online pada barang/jasa. Pengguna internet di Indonesia 
lebih cenderung hanya menggunakan internet sebatas berinteraksi pada sosial media dan juga pencarian informasi.

Berdasarkan data tersebut, penulis menyimpulkan bahwa mayoritas pengguna internet lebih suka untuk melakukan transaksi jual beli secara konvensional yang mempertemukan antara penjual dan pembeli pada waktu dan tempat yang sama dibandingkan dengan melakukan belanja online dengan media internet. Meskipun cenderung lebih merepotkan dan mengeluarkan biaya dan waktu yang lebih banyak, alasan kekhawatiran akan terjadinya penipuanmenjadi pertimbangan konsumen dalam melakukan transaksi online. Physical evidenceakan kualitas produk atau jasa serta harga yang cenderung lebih mahal dan sulit untuk dinegosiasikan menjadi faktor lain yang menyebabkan masih bertahannya transaksi konvensional ini.Di sisi lain, Mittal (2013) menyebutkan bahwatoko tradisional atau konvensional memiliki keterbatasan barang, dan biaya jual lebih tinggi daripada toko online.

Studi yang dilakukan oleh perusahaan Parago mengidentifikasi perilaku konsumen dalam melakukan riset produk mempengaruhi minat pembelian dan pada akhirnya bermuara pada loyalitas suatu produk secara online (Sekar, 2014). Mayoritas konsumenakan melakkan pencarian informasi dengan mesin pencari (search engine) seperti google, yahoo atau bing yang kemudian melakukan perbandingan harga dan juga kualitas produk. Search Engine Optimization (SEO) perlu digunakan dan terus di perbaharui guna memperbesar peluang dikunjunginya website perusahaan.

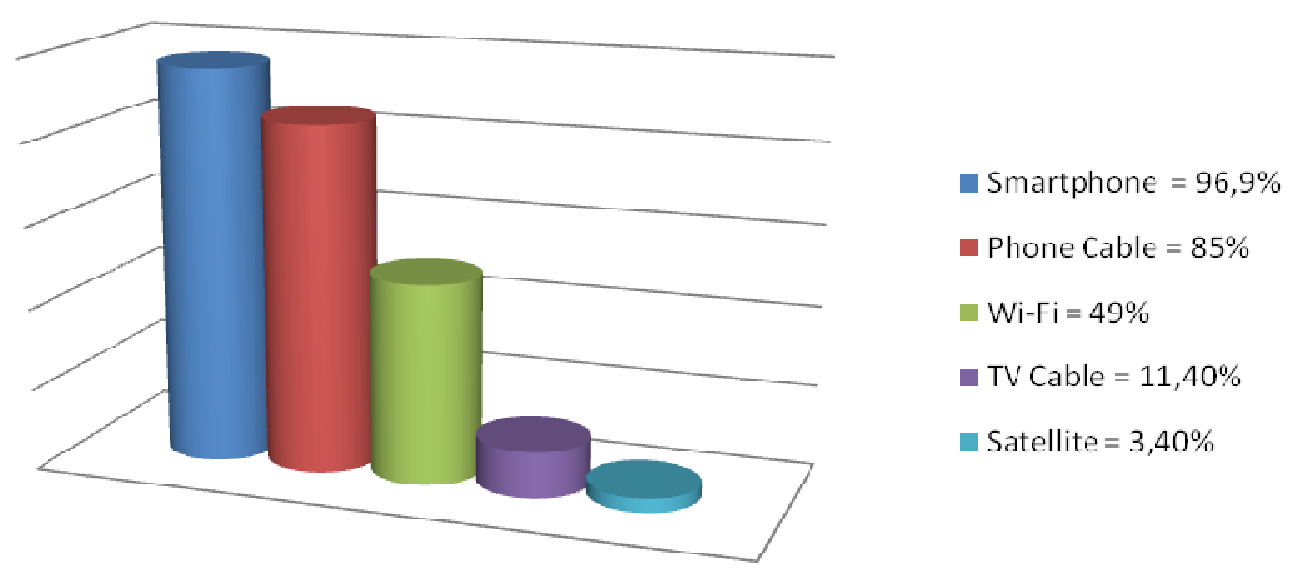

Gambar 1: Media Akses Internet Sumber: APJII, 2012
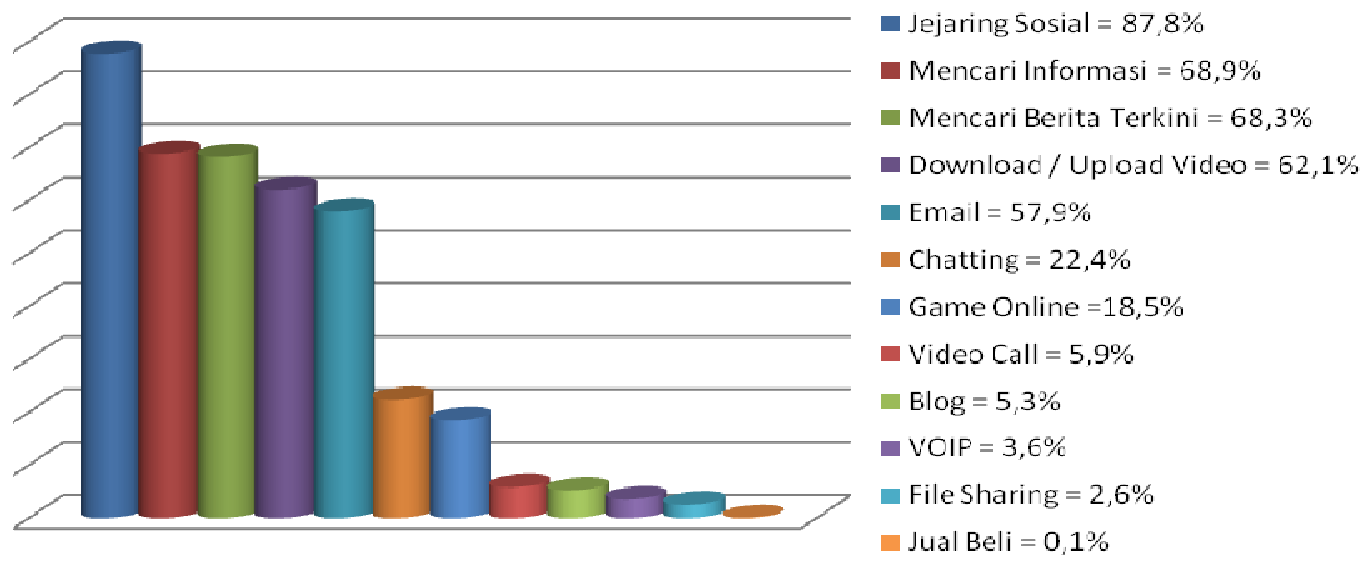

Gambar 2: Tujuan Mengakses Internet Sumber: APJII, 2012 
Loyalitas merek website memiliki pengaruh terhadap konsumen dalam buying decision process atau keputusan proses pembelian. Riset tersebut menemukan bahwa dalam industri pakaian influencermemiliki pengaruh signifikan terhadap loyalitas merek dalam. Alasannya, pakaian merupakan sebuah proses konsumsi pribadi yang membutuhkan lebih banyak kepercayaan konsumen terutama dalam hal kualitas.

Menurut Khumar dan Shah (2004) loyalitas konsumen berdasar pada tiga hal yaitu pertama, kepercayaan dimana konsumen harus mempercayai produk yang ditemukan. Kedua, transaksi atau hubungan harus memiliki nilai positif yang diperoleh lebih baik dan lebih besar dari kompetitor. Ketiga, jika kedua hal tersebut dapat terlaksana maka pemasar akan mampu menciptakan tingkat emosional yang positif pada pelanggan.

Di Indonesia, website e-commerce sudah mulai tumbuh dimana diikuti dengan meningkatnya perilaku konsumen dalam melakukan proses konsumsi baik itu secara online maupun offline. PT Bhinneka Mentari Dimensi atau yang lebih dikenal dengan Bhinneka.com merupakan salah satu situs $e$ commerce asli dari Indonesia. Penjualannya dilakukan melalui internet (e-commerce) dan juga tetap secara konvensional dengan membuka offline store (Bhinneka.com, 2014). Fenomena yang terjadi pada saat itu masyarakat tidak tanggap terhadap penggunaan transaksi yang dilakukan secara online, sehingga banyak toko online yang kurang diminati untuk dilakukan transaksi dimana juga berdasarkan fakta bahwa masih banyak konsumen yang ingin melihat produk secara langsung.

Berdasarkan data dari situs penghitung peringkat website (web page rank)Alexa.com, (2015) saat ini Bhinneka.com menempati urutan 95 website yang paling sering dikunjungi didalam negeri. Meskipun menempati 100 besar website di Indonesia, Bhinneka justru tertinggal jauh dengan kompetitor seperti Lazada.co.id (peringkat 12) dan Zalora.co.id (peringkat 50) dalam bisnis $\mathrm{B} 2 \mathrm{C}$ e-commerce di Indonesia. Penulis menduga hal ini disebabkan mulai menurunnya frekuensi promosi yang dilakukan Bhinneka.com terutama pada Broadcast Media dibandingkan dengan kompetitor. Konsumen mulai banyak yang meninggalkan
Bhinneka.com dan mulai mencari website baru sebagai pemenuhan kebutuhan.

Tabel 1:Peringkat Website B2c Di

IndonesiaPer 18 Maret 2015

\begin{tabular}{cl}
\hline Peringkat & \multicolumn{1}{c}{$\begin{array}{c}\text { Nama Website } \\
\text { e-commerce }\end{array}$} \\
\hline 12 & Lazada.co.id \\
50 & Zalora.co.id \\
95 & Bhinneka.com \\
96 & Agoda.com \\
119 & Traveloka.com \\
128 & Blibli.com \\
159 & Tiket.com \\
186 & Groupon.com \\
\hline
\end{tabular}

Sumber: Alexa.com, Maret 2015

Kondisi ini menunjukkan adanya peningkatan daya saing dalam perdagangan elektronik (e-commerce) baik dalam bentuk produk maupun jasa sejalan peningkatan kesadaran pengguna internet. Sebagai pengguna internet, konsumen kini semakin aktif dan cermat dalam memilih dan menilai situs yang akan dikunjungi. Oleh karena itu, penting bagi penyedia situs e-commerce untuk bersaing dengan kompetitor lain dengan memperhatikan unsurunsur yang dapat meningkatkan traffic atau kunjungan konsumen.

Kepuasan konsumen tidak selamanya disebabkan oleh faktor e-service quality dari website yang dikunjunginya. Penawaran yang diberikan, informasi produk, harga dan juga desain website mempunyai peranan penting dalam menghasilkan kepuasan konsumen dalam menggunakan sebuah website e-commerce (Symanski dan Hise pada Shu-Chiung, ShengWei, Chin-Yen, Ying-Ping, dan Pei-Hwa, 2011). Pada penelitian yang dilakukan oleh (Gronroos et al. pada Kim dan Kim, 2010) menyebutkan bahwa peningkatan e-service quality akan membuat website e-commerce lebih menarik dan bernilai yang nanti membantu untuk mencapai kepuasan pelanggan yang lebih tinggi.

Tujuan dari penelitian ini adalah menjawab rumusan masalah yang telah dijabarkan di atas yang berisi sebagai berikut: 1) Untuk mengetahui apakah e-service quality berpengaruh signifikan positif terhadap overall e-service quality pada website Bhinneka.com. 2) Untuk mengetahui apakah e-service quality 
berpengaruh signifikan positif terhadap $e$ satisfaction pada website Bhinneka.com. 3) Untuk mengetahui apakah overall e-service quality berpengaruh signifikan positif terhadap e-satisfaction pada website Bhinneka.com. 4) Untuk mengetahui apakah overall e-service quality berpengaruh signifikan positif terhadap e-loyalty pada website Bhinneka.com. 5) Untuk mengetahui apakah e-satisfaction berpengaruh signifikan positif terhadap e-satisfaction pada websiteBhinneka.com.

\section{KAJIAN PUSTAKA}

\section{Kajian Pustaka}

\section{Kualitas Pelayanan (Service Quality)}

Dalam memberikan pelayanan kepada konsumen, kualitas menjadi pembeda antara perusahaan satu dengan lainnya. Parasuraman, Zeithaml, dan Berry (1988) mendefinisikan service quality sebagai evaluasi secara keseluruhan dari pelayanan secara detail dan spesifik dari yang diberikan perusahaan terhadap apa yang konsumen ekspetasikan sebelumnya. Parasuraman, Zeithaml, dan Berry(1985) mengembangkan skala dimensi untuk kualitas pelayanan yang terdiri dari 97 indikator yang terbagi dalam 10 dimensi kualitas pelayanan. menyusutkan dimensi dari 10 menjadi 5 dimana indikator dari total 97 menjadi 22 (Parasuraman et al, 1988).

Dimensi yang dikembangkan oleh Parasuraman et al. pada Walker, Mullins, dan Larreche, (2008) tersebut adalah: 1) tangibles dimana berupa fasilitas fisik yang ditampilkan, peralatan yang digunakan, penampilan serta bahasa tubuh dari karyawan; 2) reliability sebagai kemampuan perusahaan dalam menepati apa yang dijanjikan kepada konsumen secara akurat dan dapat dipercaya; 3) responsiveness berupa kesiapan perusahaan untuk membantu konsumen dan juga memberikan pelayanan yang cepat; 4)assurance sebagai bentuk pengetahuan dan kesopanan karyawan dimana mendorong keyakinan dan kepercayaan dari konsumen yang diinspirasi oleh karyawan serta; 5)empathy sebagai pemberian layanan serta perhatian individu perusahaan kepada konsumen.

Seiring dengan perkembangan jaman, service quality mengalami pengembangan definisi. Zeithaml, Bitner, dan Gremler (2013) mendefinisikan dimensi dari service quality yang terdiri dari: 1) tangibles adalah representasi fisik ataupun gambar dari pelayanan yang diberikan dimana pelayanan ini digunakan untuk industri yang konsumennya langsung mengunjungi dan langsung menerima pelayanan tersebut; 2) reliability adalah bagaimana perusahaan memberikan serta mampu menepati janji-janji yang di sampaikan kepada konsumen seperti pengiriman, penyediaan layanan, penyelesaian masalah serta terkait harga; 3) responsiveness sebagai penekanan terhadap perhatian dan ketepatan perusahaan dalam berinteraksi dengan konsumen seperti permintaan informasi, pertanyaan, keluhan dan penyelesaian masalah; 4) assurance bagaimana menginspirasi dan menimbulkan keyakinan serta kepercayaan terkait konsumen yang merasa adanya resiko tinggi dan ketidakmampuan dalam mengevaluasi serta; 5) empathy dimana penyampaian layanan secara pribadi dimana dipersepsikan konsumen sebagai sosok yang unik dan khusus dimana kebutuhannya perlu dipahami dan dilayani.

Bloemer dan Kasper (1995); Yi (1990); Bastos dan Gallego (2008) menunjukkan bahwa produk dan kualitas layanan merupakan hal penting yang dapat mendorong kepuasan dan loyalitas pelanggan. Kualitas layanan mempengaruhi loyalitas baik secara langsung maupun tidak langsung melalui kepuasan pelanggan (Bloemer, 1998; Caruana, 2002).

Menurut Seth dan Deshmukh (2005) service quality outcome akan mempengaruhi harapan pelanggan terhadap layanan tertentu, dimana dapat berubah seiring perubahan waktu, service encounter, dan competitive environment. Peningkatan layanan dalam porsi yang besar dilakukan pada beberapa organisasi baik regional, nasional maupun global sebagai media untuk memperoleh aliran pendapatan (Mosahab, Mahamad, dan Ramayah, 2010).

\section{Kualitas Pelayanan Elektronik (E-Service Quality)}

Perkembangan pemasaran elektronik (e-marketing) membuat banyak perusahaan harus mengerti sudut pandang konsumen dalam mengevaluasi kualitas pelayanan yang dilakukan pada media digital seperti website, sertaapa saja kriteria yang digunakan untuk menilai hal tersebut jika dibandingkan dengan kualitas pelayanan non-internet(Kim dan Kim, 2010). 
Rolland dan Freeman (2010) mendefinisikan e-service quality dimana sebuah website dapat memfasilitasi proses belanja, pembelian dan sampai ke tahap pengiriman barang dan jasa secara efektif dan efisien, serta menyimpulkan bahwa konsumen harus bergantung sepenuhnya pada teknologi informasi dalam kegiatan e-commerce mereka. Santos (2003) mendefinisikan service quality yang dilakukan pada e-commerce/online website $(e$ service quality) sebagai sebuah evaluasi dan penilaian keseluruhan oleh konsumen atas keunggulan dan pelayanan elektronik yang diberikan dan ditawarkan pada sebuah pasar digital.

Gommans, Krishnan, dan Scheffold. (2001); Lee dan Lin (2005)menemukan bahwa website design, reliability, responsiveness dan trust mempengaruhi overall service quality dan customer satisfaction. Evaluasi positif dari dari e-service quality dapat mempengaruhi secara positif tingkat kepuasan konsumen, sikap pelanggan terhadap situs dan perilaku berkeinginan (behavioral intention) pada layanan khusus dalam konteks dari konten (Carlson dan O'Cass, 2010; Carlson dan O'Cass, 2011; Gounaris, Dimitriadis, dan Sthathakopoulos, 2010). Menurut penelitian Ghane,Fathian, dan Gholamian (2011), meski service quality, $e$ satisfaction, dan e-trust memiliki dampak langsung pada e-loyalty, namun akibat dampak tidak langsungnya menunjukkan hasil yang lebih signifikan (e-satisfaction dan e-trust sebagai mediator).

E-service quality berperan penting dalam mempengaruhi nilai yang diperoleh (perceived value) dari online shoppers'(Chen, Tsai, Hsu, dan Lee, 2013). Menurut Cristobal, Flavian, dan Guinalu (2007) perceived quality merupakan konstruk multidemensional yang dapat diperoleh melalui web design, customer service, assurance, dan order management. Dengan demikian, $e$-service quality yang diperoleh konsumen (perceived quality) akan mempengaruhi kepuasan pelanggan dan melalui kepuasan pelanggan akan mempengaruhi loyalitas pelanggan (Ribbink, Riel, Liljander, dan Streukens 2004; Yang dan Peterson; 2004 Cristobal, et al. 2007).

Berangkat dari Abels, White, dan Hahn (1998) dan Santos (2003) menggunakan enam dimensi e-service quality sebagai pengukur pelayanan dalam sebuah website yang dijadi- kan model konseptual untuk kualitas pelayanan elektronik. Sebuah tampilan design yang baik akan menciptakan profit dan juga kontribusi kepada perusahaan terutama yang berfokus pada e-commerce. Kualitas pelayanan elektronik terutama pada perusahaan e-commerce tak hanya mampu memberikan keunggulan dalam persaingan bisnis melainkan juga membangun relasi berkelanjutan antara perusahaan dengan konsumen dimana turut membantu dalam pengembangan pasar dan produk.

Parasuraman, Zeithaml, dan Malhotra (2005) mendefinisikan e-service quality secara luas mencakup semua tahap yang dilakukan oleh konsumen dengan sebuah website dimana website tersebut memberikan fasilitas dalam berbelanja, melakukan pembelian dan sampai ke tahap pengiriman secara efektif dan efisien. Kemudian Parasuraman et al. (2005) mengemukakan metode baru terkait kualitas pelayanan yang dilakukan pada media digital. Kualitas pelayanan elektronik (e-service quality) terdiri dari 4 dimensi dasar dengan 22 indikator yang terdiri dari: 1)fulfillment yakni terkait sejauh mana penepatan janji perusahaan akan ketersediaan barang, stok, dan juga terkait pengiriman pesanan; 2) efficiency yaitu seberapa mudah dan cepat dalam mengakses dan menggunakan website; 3) privacy yang menjadi indikator terkait level keamanan dan juga proteksi terkait data pribadi konsumen serta; 4) system availability terkait fungsi teknis pada website yang digunakan.

Zeithaml et al. (2013) mendefinisikan e-service quality sebagai sejauh mana sebuah website memberikan fasilitas kepada konsumen dalam melakukan kegiatan belanja, pembelian serta pengiriman secara efektif dan efisien. Zeithaml pada Chaffey, Ellis-Chadwick, Mayer, dan Johnston (2009) memberikan definisi baru seiring dengan perkembangan waktu dimana: 1) efficiency yang mengacu pada kemampuan konsumen dalam mencari website, menggunakan dan sampai ke tahap melakukan transaki yang sesuai dengan kebutuhan; 2) fulfilment sebagai pemenuhan atas apa yang dijanjikan dalam sebuah website seperti kondisi stok terkini dan detail pengiriman suatu barang; 3) reliability dimana adalah fungsi teknikal dari suatu website seperti performa yang ditampilkan; dan 4) privacy berupa jaminan dari pihak website akan kerahasian data dari perilaku konsumen selama melakukan aktifitas belanja di 
website tersebut dan juga informasi kartu kredit/debit yang aman dan tidak dibocorkan ke pihak luar.

Selain itu, sumber yang sama juga mengikuti Parasuraman et al. (2005) untuk menggunakan e-recovery service quality yang terdiri dari: 1) responsiveness berupa dukungan yang tepat dari website akan setiap pertanyaan yang muncul ataupun permintaan akan suatu informasi; 2) compensation dimana tersedianya fitur untuk melakukan proses retur barang dan retur uang yang telah dibayarkan atas pembatalan suatu transaksi serta; 3 ) contact sebagai fasilitas yang diberikan kepada konsumen melakukan komunikasi langsung pada website dengan pihak perusahaan.

E-service quality menjadi salah satu kriteria penting guna menunjang perkembangan dalam website e-commerce di dunia. Penulis menggunakan 7 dimensi e-service quality yang di kemukakan oleh Parasuramanet al. (2005) guna mengukur persepsi konsumen pada kualitas pelayanan elektronik. Dimensi yang digunakan terdiri dari empat dimensi $e$ service quality (efficiency, system availability, fulfillment dan privacy) dan tiga dimensi e-rec service quality (responsiveness, compensation dan contact). Empat dimensi awal terkait dengan inti dari pelayanan yang dilakukan secara online sedangkan tiga dimensi berikutnya fokus terhadap pelayanan akan suatu permasalahan dan penyelesaiannya. Secara lebih singkat, $e$-service quality berkaitan dengan persepsi dari konsumen terhadap kualitas pelayanan elektronik saat konsumen tidak mengalami permasalahn dengan website tersebut. Sedangkan e-rec service quality berkaitan dengan masalah yang dihadapi selama melakukan proses pembelian (Kim dan Kim, 2010).

\section{Kepuasan Konsumen (Customer Satisfaction)}

Banyak peneliti yang membahas perihal kepuasan konsumen dan berbagai faktor yang mempengaruhinya. Zeithaml et al. (2013) mendefinisikan kepuasan konsumen sebagai respon atas terpenuhinya apa yang diharapkan atau di ekspetasikan oleh konsumen berdasarkan fitur dan spesifikasi produk atau jasa, yang memiliki jenjang tingkat terkait pemenuhan konsumsi tersebut. Kepuasan konsumen didefinisikan secara konseptual sebagai suatu evaluasi paska menilai suatu transaksi, yaitu suatu perbandingan antara ekpektasi atau harapan akan nilai yang diperoleh pelanggan sebelum seseorang mengkonsumsi produk atau jasa dan setelah mengkonsumsi produk atau jasa tersebut (Bastos and Gallego, 2008).

Peter dan Olson (2010, p.387) mengatakan bahwa kepuasan konsumen adalah sebuah konsep penting dalam pemasaran dan riset konsumen. Konsumen diniai puas jika seseorang cenderung untuk terus melakukan pembelian dan memberitahukan kepada pihak lain terkait pengalaman mereka. Jika tidak puas, konsumen akan beralih ke produk atau merek yang lain dan memberikan keluhan kepada produsen, pengecer dan konsumen lainnya. Dengan demikian, kepuasan konsumen dapat diartikan sejauh mana suatu produk atau jasa minimal memenuhi atau mungkin melebihi harapan konsumen. Kepuasan dan ketidakpuasan konsumen adalah perasaan secara keseluruhan tentang produk setelah membeli dan menggunakan sebuah produk atau jasa (Salomon, 2011, p.393). Perasaan puas dan tidak serta pengalaman tersebut disampaikan secara langsung kepada orang lain maupun menulis pada blog.

Chaffey et al. (2009, p.337) menjelaskan kepuasan konsumen mengacu pada tingkat kebahagiaan konsumen atas kualitas produk dan jasa yang mereka terima. Dengan naiknya tingkat kepuasan konsumen, maka loyalitas dan perilaku mereka akan mengikuti. Kepuasan memiliki efek mediasi antara dimensi kualitas layanan (tangibles, reliability, responsiveness, empathy dan assurance) dan loyalitas pelanggan (Mahammad, Ramayah, dan Mosahab, 2010). Perusahaan yang memiliki nilai yang tinggi dalam hal kepuasan konsumen akan memiliki keunggulan kompetitif (competitive adavantage) yang besar (Salomon, 2011).

Rust dan Oliver pada (Shu-Chiung et $a l .$, 2011) menyatakan bahwa kepuasan konsumen adalah sebuah cerminan dari seberapa percaya konsumen terhadap kepemilikan maupun penggunaan suatu layanan yang menimbulkan sebuah perasaan positif. Menurut Shu-Chiung et al. (2011), kepuasan juga bisa dikonseptualisasikan sebagai kepuasan atas suatu transaksi yang terjadi, akumulasi maupun kepuasan secara keseluruhan.

Kepuasan Konsumen Elektronik (e-Satisfaction) E-satisfaction didefinisikan sebagai kepuasan terhadap pengalaman pembelian sebelumnya 
yang diberikan oleh sebuah perusahaan $e$ commerce. (Anderson dan Srinivasan, 2003). Lee dan Wu pada Sanayei dan Jokar (2013) menyatakan bahwa kepuasan konsumen mengacu pada seberapa konsumen bahagia dan puas terhadap pengalaman pembelian secara online. Dalam penelitiannya, mereka mengatakan bahwa kepuasan elektronik mengacu pada tingkat kepuasan konsumen dari desain website, isi dan informasi yang tersedia, bagaimana tersedianya fasilitas berbelanja serta keamanan yang baik.

E-satisfaction meliputi prasangka konsumen mengenai pengalaman layanan Internet sehingga mereka dapat membandingkan pengalaman tersebut dengan pengalaman layanan toko retail tradisional (Rachjaibun, 2007) dalam (Afsar, Nasiri, dan Zadeh, 2013). Dalam penelitian Asgari,Hamid, Asgari, dan Mousavipour (2012); Flavian, Guinaliu, dan Gurrea (2006); Ariff, Yun, Zakuan, dan Ismail (2013)mengatakan bahwa jika pelanggan dapat memperoleh informasi melalui situs tanpa mengalami kesulitan teknis, maka pelanggan akan merasakan e-satisfaction dan akan menghasilkan e-loyalty. Pelanggan akan memperoleh kualitas layanan dalam website, berdasar pengalaman dengan fungsi website.

Garbarino dan Johnson pada Jin, Park, dan Kim.(2008) mengkonsepkan e-satisfaction sebagai tingkatan umum atas kepuasan pelanggan yang berdasarkan pengalaman sebelumnya pada website, bukan pada evaluasi dan emosi sementara serta transaksi yang spesifik.

Dalam konteks digital, customer esatisfaction didefinisikan oleh Hisea dan Szymanski pada Al-Hawari (2014) sebagai efek kumulatif dari sekelompok orang dengan pengalaman terhadap penyedia layanan selama periode waktu tertentu. Sedangkan, e-satisfaction dalam arti luas mengukur tingkat evaluasi secara keseluruhan dari pelanggan atas pengalaman belanja online. Dalam penelitian Chung dan Shin (2008), mereka menemukan bahwa informasi produk (good information of product) lebih memberikan dampak positif pada e-satisfaction dibanding kenyamanan belanja e-retailing (shopping convinience). Szymanski dan Hise (2000) menemukan convi- nience, site design, dan financial security sebagai faktor dominan dalam penilaian $e$ satisfaction. Menurut Shankar, Smith, dan Rangaswamy (2003) tingkat kepuasan pelanggan memiliki hubungan yang kuat dan saling mendorong dengan loyalitas pelanggan baik menggunakan onlineatau offline shopping.

\section{Loyalitas Konsumen secara Elektronik (Customer e-Loyalty)}

Menurut Dick dan Basu (1994) loyalitas didefinisikan sebagai hubungan antara perilaku yang ditunjukan oleh seseorang terhadap merek/produk/toko dan perilaku berlangganan. Oliver (1999) telah meneliti loyalitas, bahwasannya pemenuhan kebutuhan untuk pelanggan harus disertai dengan memberikan nilai unggul yang berasal dari pelayanan prima dan produk berkualitas. Loyalitas layanan merupakan salah satu struktur penting dalam layanan pemasaran berupa pembelian ulang oleh pelanggan dan pelanggan loyal yang melakukan pembelian secara ulang menjadi pertimbangan untuk bisnis lainnya (Caruana, 2002).

E-loyalty meliputi keinginan akan kecenderung konsumen terhadap e-retailing dan hasilnya dalam suatu perilaku pembelian ulang. Rachjaibun (2007) mengatakan bahwa pelanggan loyal merupakan salah satu penggerak penting untuk kesuksessan e-commerce. Srinivasan Anderson, dan Ponnavolu. (2002) menunjukkan bahwa e-loyalty seperti memiliki dampak positive pada dua pelanggan dengan hasil yang saling berhubungan yaitu suatu keinginan untuk membayar lebih (willingness to pay more) dan WOM promotion.

Cyr (2008) mendefinisikan e-loyalty sebagai niat dari konsumen untuk mengunjungi atau menggunakan suatu website melakukan pembelian atau mempertimbangkan membeli dari website tersebut di masa depan dimana konsumen tidak akan berpindah ke website lain. Sedangkan Jin et al. (2008); Anderson dan Srinivasan (2003); Ał Hawari, (2014) mendefinisikan e-loyalty sebagai perilaku pembelian berulang (repurchase) pada suatu website selama periode waktu tertentu yang didorong atas keinginan untuk mendapatkan keuntungan termasuk aspek sikap dan perilaku. 


\section{Penelitian Sebelumnya}

\begin{tabular}{|c|c|c|}
\hline No & & Keterangan \\
\hline \multirow[t]{7}{*}{1} & Penulis & A Parasuraman, Valarie A Zeithaml, dan Arvind Malhotra \\
\hline & Judul & E-S-Qual: A Multiple Item Scale for Assesing Electronic Service Quality \\
\hline & Tahun & 2005 \\
\hline & Variabel & E-SQ, E-RecSQ, Perceived Value dan Loyalty \\
\hline & Responden & 200 responden \\
\hline & Tempat & USA \\
\hline & Hasil Penelitian & $\begin{array}{l}\text { E-SQ memiliki pengaruh signifikan positif terhadap Perceived Value dan Loyalty } \\
\text { pada konsumen Amazon dan Walmart }\end{array}$ \\
\hline \multirow[t]{7}{*}{2} & Penulis & Jung-Hwan Kim dan Chungho Kim \\
\hline & Judul & $\begin{array}{l}\text { E-service quality perceptions: a cross-cultural comparison of American and } \\
\text { Korean consumers }\end{array}$ \\
\hline & Tahun & 2010 \\
\hline & Variabel & E-SQ, Overall E-SQ, E-Satisfaction dan E-Loyalty \\
\hline & Responden & 209 responden di US dan 211 responden di Korea Selatan \\
\hline & Tempat & United Stated dan Korea Selatan \\
\hline & Hasil Penelitian & $\begin{array}{l}\text { Terdapat pengaruh signifikan positif atas Overall E-SQ pada E-Satisfaction } \\
\text { Terdapat pengaruh positif Overall E-SQ dan E-Satisfaction terhadap E-Loyalty }\end{array}$ \\
\hline \multirow[t]{7}{*}{3} & Penulis & $\begin{array}{l}\text { Shu-Chiung Lin, Sheng Wei Lin, Tan Chin Yen, Ying-Ping Yu, dan Pei-Hwang } \\
\text { Yang }\end{array}$ \\
\hline & Judul & $\begin{array}{l}\text { How E-Servqual Affects Customer Online Purchase Intention Through Cross- } \\
\text { Culture Comparison }\end{array}$ \\
\hline & Tahun & 2011 \\
\hline & Variabel & E-SQ, Satisfaction, Trust, dan Purchase Intention \\
\hline & Responden & 120 responden di Taiwan dan 118 responden di Malaysia \\
\hline & Tempat & Taiwan dan Malaysia \\
\hline & Hasil Penelitian & $\begin{array}{l}\text { Di Taiwan, } E-S Q \text { memiliki pengaruh signifikan terhadap Satisfaction dan Trust } \\
\text { dimana keduanya akan menghasilkan Purchase Intention } \\
\text { Sedangkan di Malaysia, E-SQ memiliki pengaruh terhadap Satisfaction namun } \\
\text { tidak terhadap Trust, dan PurchaseIntention tidak di hasilkan oleh Satisfaction } \\
\text { namun dari Trust. Hal ini di sebabkan oleh kecepatan internet di negara tersebut } \\
\text { dan juga pengalaman berbelanja onlinekonsumen di Malaysia yang tidak setinggi } \\
\text { di Taiwan. }\end{array}$ \\
\hline \multirow[t]{9}{*}{4} & Penulis & Gwo-Guang Lee dan Hsiu-Fen Lin \\
\hline & Judul & Customer Perceptions of E-Service Quality in Online Shopping \\
\hline & Tahun & 2005 \\
\hline & Variabel & E-SQ, Overall E-SQ, Satisfaction, Purchase Intention \\
\hline & Responden & 297 responden \\
\hline & Tempat & Taipei, Taiwan \\
\hline & Hasil Penelitian & $\begin{array}{l}\text { Mayoritas dimensi E-SQ berpengaruh terhadap Overall E-SQ dan Satisfaction } \\
\text { kecuali dimensi Personalization }\end{array}$ \\
\hline & & $\begin{array}{l}\text { Overall } E-S Q \text { memiliki pengaruh positif yang kuat terhadap Satisfaction } \\
\text { konsumen. }\end{array}$ \\
\hline & & $\begin{array}{l}\text { Overall E-SQ dan Satisfaction berpengaruh signifikan terhadap PurchaseIntention } \\
\text { konsumen }\end{array}$ \\
\hline \multirow[t]{7}{*}{5} & Penulis & Suresh Kandulapati dan Raja Shekhar Bellamkonda \\
\hline & Judul & E-Service Quality: a study of online shoppers in India \\
\hline & Tahun & 2014 \\
\hline & Variabel & E-SQ, Perceived Service Value, dan Customer Satisfaction \\
\hline & Responden & 160 responden \\
\hline & Tempat & India \\
\hline & Hasil Penelitian & E-SQ memiliki pengaruh yang signifikan terhadap Service Value dan bermuara \\
\hline
\end{tabular}




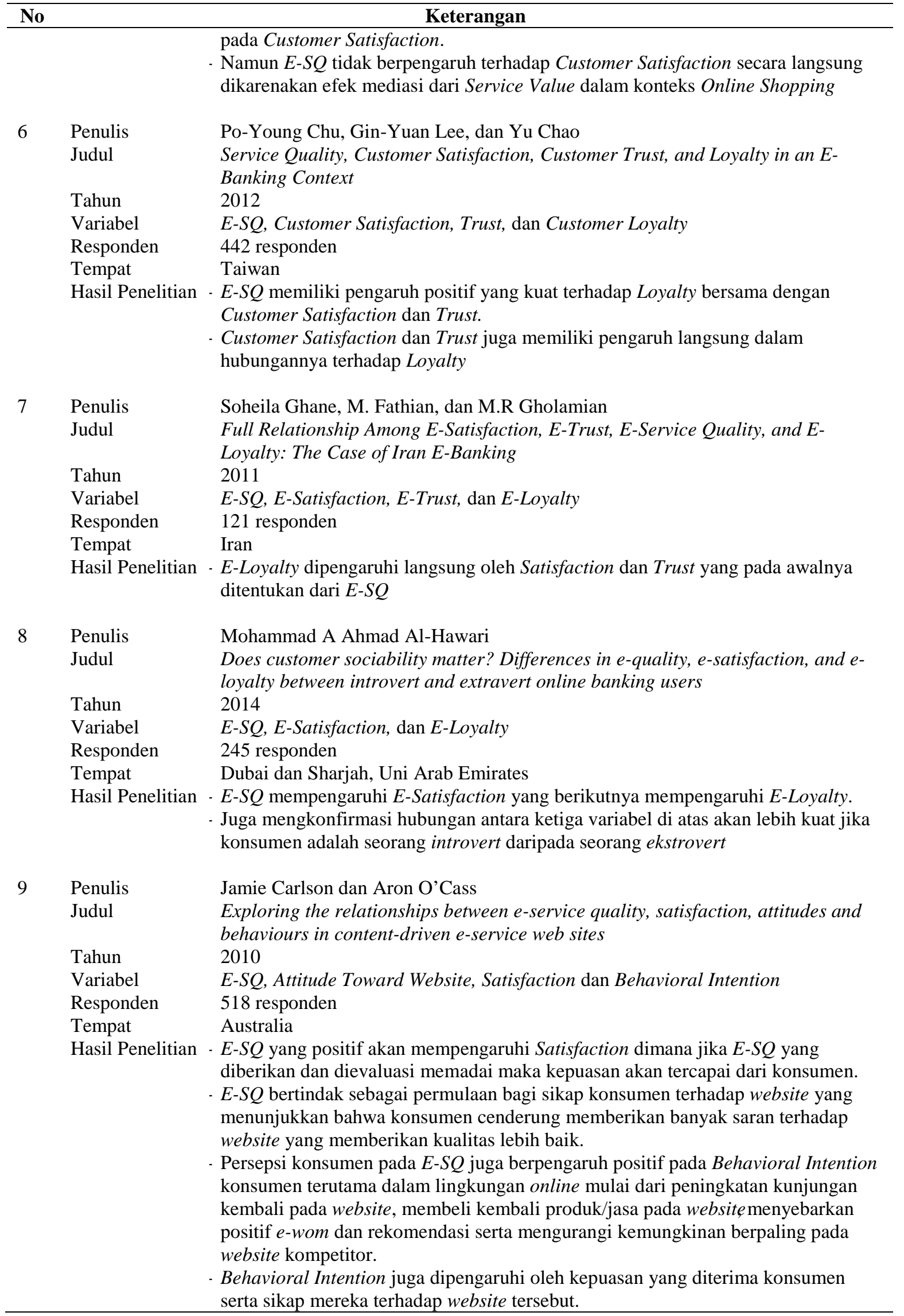




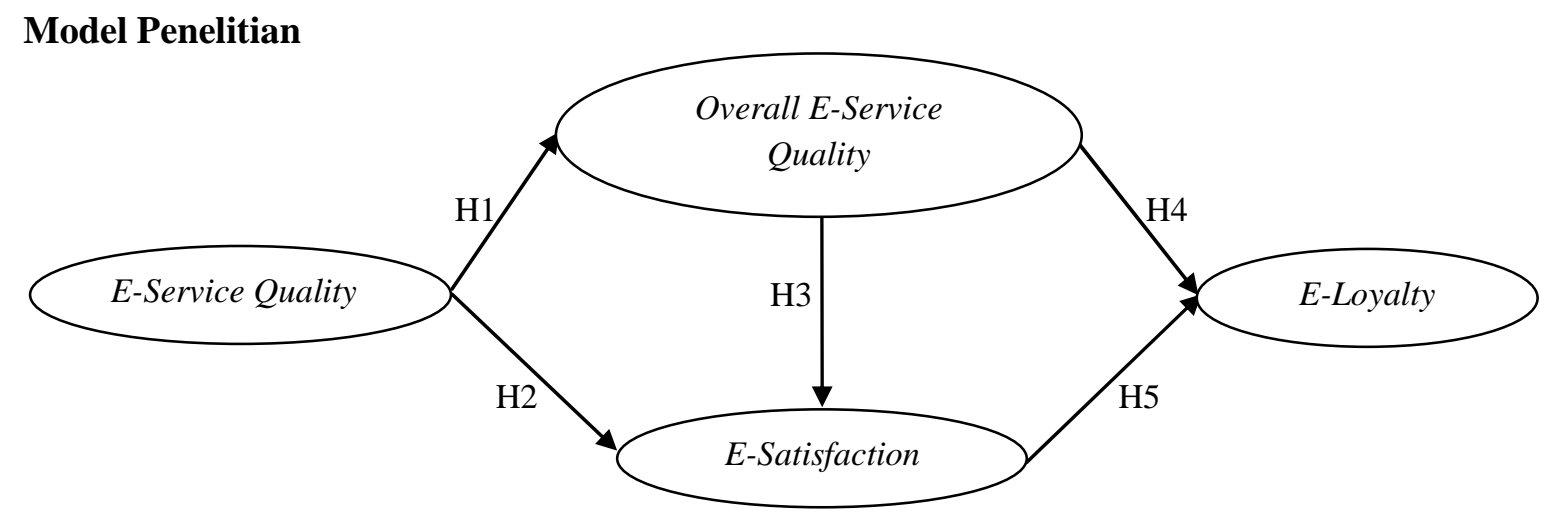

Sumber: Kim dan Kim (2010)

Gambar 1: Model Penelitian

Model penelitian yang digunakan dalam penelitian ini adalah hasil replika dari penelitian sebelumnya yang mengadopsi dari penelitian Kim dan Kim (2010).

\section{METODOLOGI PENELITIAN}

\section{Metode Pengumpulan Data}

\section{Jenis dan Teknik Penelitian}

Penelitian yang akan dilakukan penelitian sebab akibat (causal study) dimana penelitian ini untuk menemukan penyebab dari satu atau lebih masalah (Sekaran, 2011). Lebih lanjut lagi Malhotra (2012,p.108) menjelaskan bahwa riset kausal bersifat sebab akibat pengaruh antara variabel independen terhadap variabel dependen. Penulis dalam penelitian ini ingin mengetahui apakah terdapat pengaruh dari variabel independen (e-service quality) terhadap variabel dependen (overall e-service qualit dan e-satisfaction)dan hubungan keduanya terhadap e-loyalty.

Teknik pengumpulan data sangat penting dalam penelitian ini dimana penelitian ini bersifat penelitian kuantitatif yang merupakan kajian dengan menggunakan analisis statistik untuk mendapatkan temuan dimana ciri utama dari penelitian ini adalah pengukuran formal dan sistematis dan penggunaan statistik (Suharsaputra, 2012, p.49). Penelitian ini menggunakan metode kuesioner dan kepustakaan untuk mengumpulkan data yang diperlukan.

\section{Populasi dan Sampel}

Sekaran dan Bougie (2013, p.240) mendefinisikan populasi sebagai seluruh kelompok orang, peristiwa yang ingin diselidiki oleh peneliti guna membuat suatu kesimpulan dengan berdasarkan statistik sampel. Populasi dalam penelitian ini adalah seluruh konsumen Bhinneka.com yang pernah melakukan pembelian pada website tersebut secara online. Jumlah populasi tidak diketahui.

Sampel menurut Sekaran dan Bougie (2013,p.241) adalah sebagian dari populasi. Sampel terdiri atas sejumlah anggota yang dipilih dari populasi. Dengan kata lain, sejumlah tetapi tidak semua, elemen populasi akan membentuk sampel. Bila 200 pelanggan diambil dari populasi 1000 pelanggan, 200 pelanggan itu akan menjadi sampel penelitian.Teknik pemilihan sampel yang digunakan adalah nonprobability sampling. Dalam penelitian ini berhasil diambil 219 sampel.

\section{Metode Analisis}

Dalam penelitian ini, peneliti menggunakan skala likert atau dengan tujuh titik untuk menelaah seberapa kuat subjek setuju atau tidak setuju dengan pernyataan. Sekaran dan Bougie (2013,p.220) mengatakan bahwa skala rating memberikan flesibilitas untuk digunakan sebanyak titik yang di anggap perlu guna keperluan penelitian (4, 5, 7, 9 atau lainnya) dan juga memungkinkan menggunakan jangkar sebagai titik netral maupun tidak. Jumlah respon dalam skala likert disarankan menggunakan dasar 7 skala untuk pilihan responden dari apa yang paling mereka sukai (Budiaji, 2013). Variabel $e$-service quality, overall e-service quality, $e$ satisfaction dan variabel e-loyalty diukur dengan skala likert 7 (tujuh) tingkat dengan besar nilai pada pada kuisioner sebagai berikut: 


\section{Operasionalisasi Variabel}

Operasional variabel atau konsep dapat dilakukan sebagai upaya dimana konsep yang abstrak bisa diukur. Konsep yang abstrak harus diurai- kan menjadi dimensi, kemudian dilakukan pengukuran misalnya dengan menggunakan pertanyaan (Supranto \& Limakrisna, 2009)

\begin{tabular}{|c|c|c|c|}
\hline Variabel & Dimensi & Indikator & Skala \\
\hline E-Service & Efficiency & Website mudah untuk diakses & $1-7$ \\
\hline \multirow[t]{30}{*}{ Quality } & & $\begin{array}{l}\text { Website memungkinkan untuk melakukan transaksi secara } \\
\text { lengkap dengan cepat }\end{array}$ & $1-7$ \\
\hline & & Informasi yang ada terorganisir dengan baik & $1-7$ \\
\hline & & Halaman website terbuka dengan cepat & $1-7$ \\
\hline & & Websitemudah untuk digunakan & $1-7$ \\
\hline & & $\begin{array}{l}\text { Website memungkinkan saya mendapatkan apa yang } \\
\text { dibutuhkan secara cepat }\end{array}$ & $1-7$ \\
\hline & & Website terorganisir secara baik & $1-7$ \\
\hline & SystemAvailability & Website selalu tersedia untuk keperluan konsumen & $1-7$ \\
\hline & & Website beroperasi dengan baik & $1-7$ \\
\hline & & Tidak mengalami kerusakan pada website & $1-7$ \\
\hline & & $\begin{array}{l}\text { Halaman pada website tidak mengalami hang saat } \\
\text { melakukan proses transaksi }\end{array}$ & $1-7$ \\
\hline & Fulfillment & Website mengirimkan pesanan sesuai dengan yang dipesan & $1-7$ \\
\hline & & Stok barang yang ada di tuliskan di website selalu ready & $1-7$ \\
\hline & & $\begin{array}{l}\text { Website mengirimkan dengan cepat dan tepat waktu apa } \\
\text { yang dipesan }\end{array}$ & $1-7$ \\
\hline & & $\begin{array}{l}\text { Website mempunyai persediaan sesuai dengan apa yang } \\
\text { perusahaan klaim }\end{array}$ & $1-7$ \\
\hline & & Penawaran yang diberikan bersifat benar adanya & $1-7$ \\
\hline & & Website menepati janji terkait pengiriman barang & $1-7$ \\
\hline & Privacy & Website melindungi data terkait pembayaran konsumen & $1-7$ \\
\hline & & $\begin{array}{l}\text { Website tidak menyebarkan data pribadi ke website yang } \\
\text { lain }\end{array}$ & $1-7$ \\
\hline & & $\begin{array}{l}\text { Website melindungi data terkait kartu kredit, debit dan lain- } \\
\text { lain }\end{array}$ & $1-7$ \\
\hline & Responsiveness & $\begin{array}{l}\text { Website memberikan pilihan yang nyaman guna meretur } \\
\text { barang yang tidak sesuai }\end{array}$ & $1-7$ \\
\hline & & Website menangani proses retur dengan baik & $1-7$ \\
\hline & & $\begin{array}{l}\text { Website menawarkan garansi yang sesuai dengan yang } \\
\text { tertera }\end{array}$ & $1-7$ \\
\hline & & $\begin{array}{l}\text { Website memberikan instruksi tutorial terkait apa yang } \\
\text { harus dilakukan saat transaksi yang dilakukan tidak bisa } \\
\text { diproses }\end{array}$ & $1-7$ \\
\hline & & Website mengurus permasalahan yang ada dengan segera & $1-7$ \\
\hline & Compensation & $\begin{array}{l}\text { Website memberikan pertanggung jawaban atas } \\
\text { permasalahan yang terjadi (bukan kesalahan dari } \\
\text { konsumen) }\end{array}$ & $1-7$ \\
\hline & & $\begin{array}{l}\text { Jika barang sudah dikirimkan, Website akan memberikan } \\
\text { notifikasi kepada konsumen }\end{array}$ & $1-7$ \\
\hline & Contact & $\begin{array}{l}\text { Tersedianya nomor telepon pada website guna konsumen } \\
\text { menghubungi langsung perusahaan }\end{array}$ & $1-7$ \\
\hline & & Tersedianya perwakilan layanan konsumen secara online & $1-7$ \\
\hline & & $\begin{array}{l}\text { Website memfasilitasi kebutuhan konsumen untuk } \\
\text { berbicara langsung dengan operator bila terjadi } \\
\text { permasalahan } \\
\quad \text { Parasuraman etal }\end{array}$ & $1-7$ \\
\hline & Overall e-Service Quality & $\begin{array}{l}\text { Parasuraman et al. (2005) } \\
\text { Secara keseluruhan website memenuhi ekspetasi saya dan }\end{array}$ & $1-7$ \\
\hline
\end{tabular}
bisa dijadikan supplier yang baik jika melakukan transaksi online 


\begin{tabular}{|c|c|c|}
\hline Variabel & Indikator & Skala \\
\hline & $\begin{array}{l}\text { Secara keseluruhan website memenuhi ekspetasi saya dan } \\
\text { bisa dijadikan supplier yang baik jika melakukan transaksi } \\
\text { online } \\
\text { Yang,Jun, dan Peterson (2004) }\end{array}$ & $1-7$ \\
\hline \multirow[t]{4}{*}{ E-Satisfaction } & Secara keseluruhan saya puas dengan website & $1-7$ \\
\hline & $\begin{array}{l}\text { Secara keseluruhan saya puas dengan transaksi yang } \\
\text { berbasis online }\end{array}$ & $1-7$ \\
\hline & $\begin{array}{l}\text { Secara keseluruhan saya puas dengan ketersediaan produk } \\
\text { website }\end{array}$ & $1-7$ \\
\hline & Yang et al. (2004) & \\
\hline \multirow[t]{4}{*}{ E-Loyalty } & $\begin{array}{l}\text { Konsumen akan terus melakukan pembelian pada website } \\
\text { tersebut }\end{array}$ & \\
\hline & $\begin{array}{l}\text { Konsumen akan merekomendasikan kepada orang lain } \\
\text { untuk menggunakan jasa } e \text {-commerce }\end{array}$ & $1-7$ \\
\hline & $\begin{array}{l}\text { Konsumen tidak akan merubah pilihan kepada website saat } \\
\text { akan melakukan pembelian pada } \text {-commerce di masa } \\
\text { depan }\end{array}$ & $1-7$ \\
\hline & $\begin{array}{l}\text { Perubahan pilihan website membutuhkan pertimbangan } \\
\text { yang besar }\end{array}$ & $1-7$ \\
\hline
\end{tabular}

Sumber: Eid, (2011)

\begin{abstract}
Alat Analisis Data
Alat analisis data yang digunakan pada penelitian ini menggunakan program Smart Partial Least Square (Smart PLS) 2.0 (Chu, Lee, \& Chao, 2012). Selain menggunakan alat analisis tersebut, model penelitian sejenis juga bisa dikelola menggunakan Linear Structural Relation (LISREL) 8.8 (Kim \& Kim, 2010).
\end{abstract}

\section{Validitas dan Reliabilitas}

Pada sebuah penelitian, perlu melakukan pengujian validitas dan reliabilitas. Hasil penelitian yang valid adalah bila terdapat kesamaan antara data yang terkumpul dengan data sesungguhnya terjadi pada objek yang diteliti. Sedangkan hasil penelitian yang reliabel adalah bila terdapat kesamaan data dalam waktu yang berbeda(Sugiyono, 2014).

\section{Structural Equation Model berbasis Partial Least Square}

Model persamaan struktural (SEM) merupakan teknik analisisi yang merupakan gabungan dari dua metodologi yaitu perspektif ekonometrika yang memfokuskan pada prediksi dan psychometrika yang mampu menggambarkan konsep model dengan variabel laten. Partial Least Square merupakan turunan dari SEM dimana merupakan metode analisisi yang disebut juga soft modeling dimana meniadakan asumsi asumsi Ordinal Least Square regresi seperti distribusi normal data secara multivariate dan tidak adanya problem multikolinearitas antara variabel eksogen (Ghozali \& Latan, 2012).

\section{Hipotesis Penelitian}

Pada penelitian ini menggunakan hipotesis penelitian beraspek statistik. Maka hipotesis yang dibuat adalah sebagai berikut: 1) Terdapat pengaruh positif yang signifikan antara variabel e-service quality dengan overall e-service quality. 2) Terdapat pengaruh positif yang signifikan antara variabel e-service quality dengan e-satisfaction. 3) Terdapat pengaruh positif yang signifikan antara variabel overall $e$-service quality dengan $e$-satisfaction. 4) Terdapat pengaruh positif yang signifikan antara variabel overall e-service quality dengan $e$ loyalty. 5) Terdapat pengaruh positif yang signifikan antara variabel $e$-satisfaction dengan e-loyalty.

\section{PEMBAHASAN}

\section{Penyajian Data}

Alat analissis dalam penelitian ini menggunakan Smart PLS 2.0 M3. Responden yang di telah di terima dari penyebaran kuesioner adalah 307 responden dimana setelah disortir untuk membedakan mana konsumen yang pernah membeli di Website Bhinneka.com atau tidak pernah. Total kuesioner yang memenuhi persyaratan adalah senilai 219 . 
Tabel 4: Karakteristik Responden

\begin{tabular}{ccc}
\hline Keterangan & Responden & Persentase \\
\hline Jenis Kelamin: & & \\
Pria & 107 responden & $48,86 \%$ \\
Wanita & 112 responden & $51,14 \%$ \\
Usia Konsumen: & & \\
$<14$ tahun $($ Gen Z) & 1 responden & $0,46 \%$ \\
$15-35$ tahun (Gen Y) & 210 responden & $95,89 \%$ \\
$36-50$ tahun (Gen X) & 7 responden & $3,20 \%$ \\
$51-69$ tahun (Baby Boomers) & 1 responden & $0,46 \%$ \\
Seberapa Lama Konsumen & & \\
Mengenal Bhinneka.com: & & \\
$<1$ bulan & 71 responden & $32,42 \%$ \\
$3-6$ bulan & 38 responden & $17,35 \%$ \\
$7-12$ bulan & 19 responden & $8,68 \%$ \\
$>12$ bulan & 91 responden & $41,55 \%$ \\
Jumlah Sampel & 219 responden & $100 \%$ \\
\hline
\end{tabular}

Sumber: Olahan Penulis, 2015

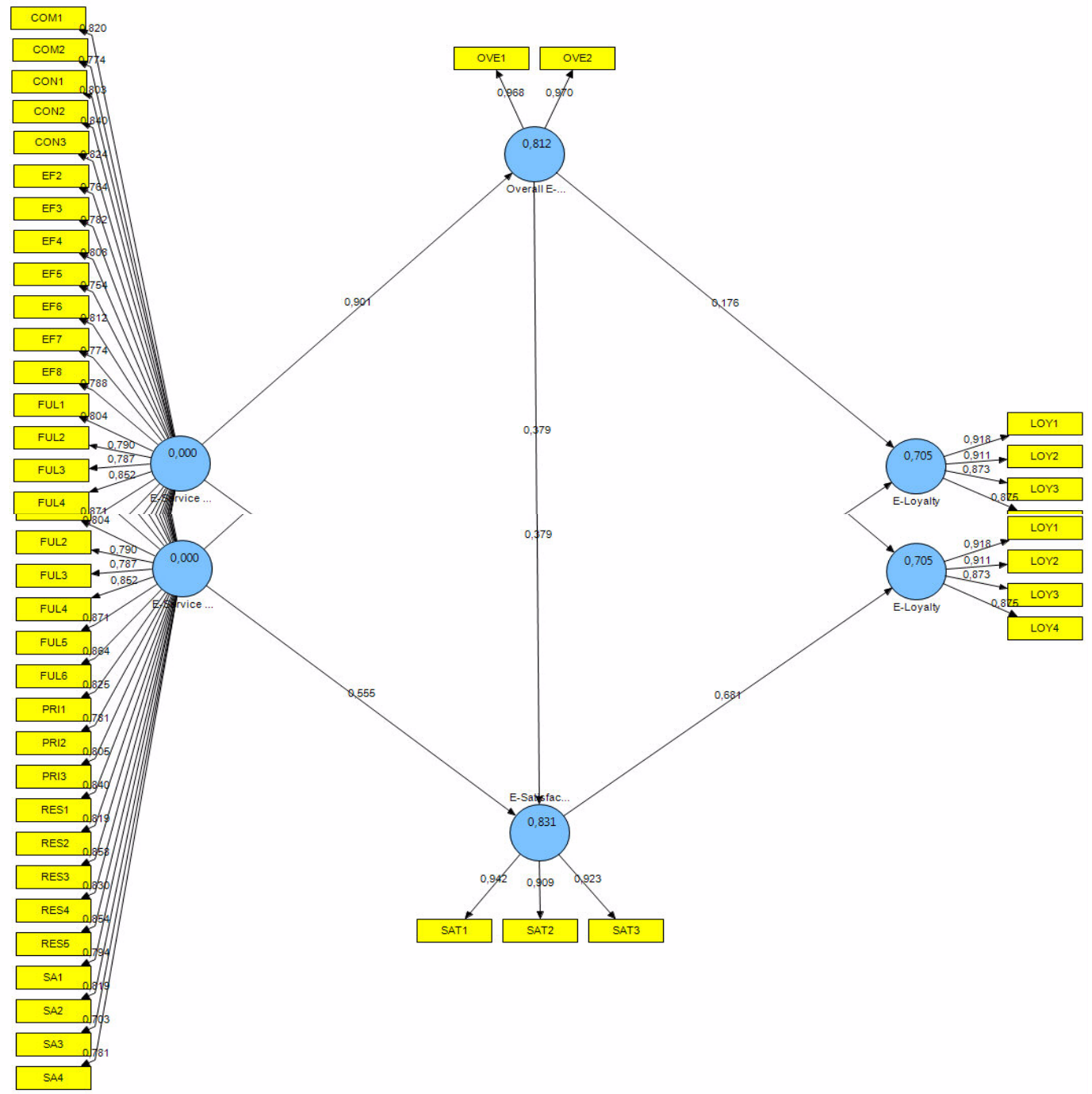

Sumber: Olahan Penulis, 2015

Gambar 2: Output PLS Algorithm 
Tabel 5: Outer Loading

\begin{tabular}{|c|c|c|c|c|}
\hline & E-Loyalty & E-Satisfaction & E-Service Quality & $\begin{array}{c}\text { Overall E-Service } \\
\text { Quality }\end{array}$ \\
\hline COM1 & & & 0,819506 & \\
\hline COM2 & & & 0,774385 & \\
\hline CON1 & & & 0,802873 & \\
\hline CON2 & & & 0,840060 & \\
\hline CON3 & & & 0,824205 & \\
\hline EF2 & & & 0,763711 & \\
\hline EF3 & & & 0,781950 & \\
\hline EF4 & & & 0,808346 & \\
\hline EF5 & & & 0,753757 & \\
\hline EF6 & & & 0,811536 & \\
\hline EF7 & & & 0,773585 & \\
\hline EF8 & & & 0,787639 & \\
\hline FUL1 & & & 0,803671 & \\
\hline FUL2 & & & 0,789712 & \\
\hline FUL3 & & & 0,787251 & \\
\hline FUL4 & & & 0,852039 & \\
\hline FUL5 & & & 0,871175 & \\
\hline FUL6 & & & 0,863816 & \\
\hline LOY1 & 0,917510 & & & \\
\hline LOY2 & 0,910653 & & & \\
\hline LOY3 & 0,873471 & & & \\
\hline LOY4 & 0,875130 & & & \\
\hline OVE1 & & & & 0,967868 \\
\hline OVE2 & & & & 0,969736 \\
\hline PRI1 & & & 0,825494 & \\
\hline PRI2 & & & 0,781491 & \\
\hline PRI3 & & & 0,805134 & \\
\hline RES1 & & & 0,840461 & \\
\hline RES2 & & & 0,819273 & \\
\hline RES3 & & & 0,858346 & \\
\hline RES4 & & & 0,829792 & \\
\hline RES5 & & & 0,853877 & \\
\hline SA1 & & & 0,793635 & \\
\hline SA2 & & & 0,819408 & \\
\hline SA3 & & & 0,703161 & \\
\hline SA4 & & & 0,781025 & \\
\hline SAT1 & & 0,941852 & & \\
\hline SAT2 & & 0,908974 & & \\
\hline SAT3 & & 0,923059 & & \\
\hline
\end{tabular}

Sumber: Olahan Penulis, 2015

Dari hasil output analisis dapat dilihat bahwa semua konstruk indikator reflektif sesuai dengan anak panah tiap variabel menghasilkan nilai outer loading factor $>0,7$ yang berarti semua indikator konstruk adalah valid (Ghozali \& Latan, 2012). Dan juga berdasarkan hasil output analisis pada tabel 5 dapat dilihat bahwa semua item e-service quality, overall e-service quality, e-satisfaction dan -loyalty menempati kolom masing-masing dan tidak terdapat di kolom indikator lain.
Tabel 6: Ave

\begin{tabular}{lc}
\hline & $A V E$ \\
\hline E-Loyalty & 0,799980 \\
E-Satisfaction & 0,855119 \\
E-Service Quality & 0,653103 \\
Overall E-Service Quality & 0,938579 \\
\hline
\end{tabular}

Hasil pengolahan data pada tabel 6 menunjukan semua konstruk reflektif menghasilkan $A V E$ dengan angka $>0,5$ sehingga memenuhi persyaratan validitas konvergen (Ghozali \& Latan, 2012). 
Tabel 7: Communality

\begin{tabular}{lc}
\hline & Communality \\
\hline E-Loyalty & 0,799980 \\
E-Satisfaction & 0,855119 \\
E-Service Quality & 0,653103 \\
Overall E-Service Quality & 0,938579 \\
\hline
\end{tabular}

Sumber: Olahan Penulis, 2015

Hasil pengolahan data pada tabel 7 menunjukan semua konstruk reflektif menghasilkan Communality dengan angka $>0,5$ sehingga memenuhi persyaratan validitas konvergen (Ghozali \& Latan, 2012).

Tabel 8: Cronbach's Alpha

\begin{tabular}{lc}
\hline & Cronbachs Alpha \\
\hline E-Loyalty & 0,916856 \\
E-Satisfaction & 0,915254 \\
E-Service Quality & 0,981591 \\
Overall E-Service Quality & 0,934573 \\
\hline
\end{tabular}

Dari tabel 8 terlihat bahwa Cronbach's Alpha yang dihasilkan semua konstruk reflektif sangat baik yaitu berada di atas $0,70(>0,70)$. Kesimpulan yang didapat adalah semua indikator reflektif adalah reliabel dan memenuhi uji reliabilitas. Composite Reliability guna menguji reliabilitas suatu konstruk (Ghozali dan Latan (2012).

Dari tabel 9 terlihat bahwa Composite Reliability yang dihasilkan semua konstruk reflektif sangat baik yaitu berada di atas 0,70 $(>0,70)$. Kesimpulan yang didapat adalah semua indikator reflektif adalah reliabel dan memenuhi uji reliabilitas. (Ghozali \& Latan, 2012).

Tabel 9: Composite Reliability

\begin{tabular}{lc}
\hline & Composite Reliability \\
\hline E-Loyalty & 0,941142 \\
E-Satisfaction & 0,946532 \\
E-Service Quality & 0,982569 \\
Overall E-Service & 0,968316 \\
Quality & \\
\hline
\end{tabular}

Sumber: Olahan Penulis, 2015
Nilai pada tabel Latent Variable Correlation pada tabel 10 menunjukkan jika nilai korelasi > 0,5 yang mana dapat diartikan sebagai adanya korelasi antara variabel laten.

Dari hasil output $R$-Square pada tabel 11 dapat dilihat bahwa nilai $R$-Square yang dihasilkan untuk variabel Overall E-Service Quality adalah sebesar 0,811623 yang berarti pengaruh E-Service Quality terhadap Overall E-Service Quality adalah sebesar 81,16\% dan sisanya dipengaruhi variabel lain diluar model penelitian ini. Untuk variabel E-Satisfaction, diperoleh nilai $R$-Square sebesar 0,83192yang berarti pengaruh E-Service Quality dan Overall E-Service Quality adalah sebesar 83,19\% dan sisanya adalah pengaruh dari variabel lain diluar model penelitian ini.

Dan untuk variabel E-Loyalty, nilai $R$ Square yang dihasilkan adalah sebesar 0,704782 yang berarti pengaruh Overall E-Service Quality dan E-Satisfaction adalah sebesar 70,48\% dan sisanya dipengaruhi variabel lain di luar model penelitian yang diangkat oleh penulis.

Tabel 11: $R$-Square

\begin{tabular}{ll}
\hline & $R$ Square \\
\hline E-Loyalty & 0,704783 \\
E-Satisfaction & 0,831162 \\
E-Service Quality & \\
Overall E-Service Quality & 0,811716 \\
\hline
\end{tabular}

Sumber: Olahan Penulis, 2015

\section{Analisa Data dan Interpretasi}

\section{Uji Signifikansi}

Pada penelitian ini, signifikansi parameter yang diestimasi memberikan informasi yang sangat berguna mengenai hubungan antara variabel variabel penelitian.

Tabel 10: Latent Variable Correlations

\begin{tabular}{lcccc}
\hline & E-Loyalty & E-Satisfaction & E-Service Quality & $\begin{array}{c}\text { Overall E-Service } \\
\text { Quality }\end{array}$ \\
\hline E-Loyalty & 1,000000 & & & \\
E-Satisfaction & 0,835317 & 1,000000 & & \\
E-Service Quality & 0,818378 & 0,896723 & 1,000000 & 1,000000 \\
Overall E-Service Quality & 0,774405 & 0,879272 & 0,900953 & \\
\hline
\end{tabular}


Tabel 12: Uji Signifikansi (Mean, Stdev, T-Values)

\begin{tabular}{lccccc}
\hline & $\begin{array}{c}\text { Original } \\
\text { Sampel } \\
(O)\end{array}$ & $\begin{array}{c}\text { Sampel } \\
\text { Mean }(M)\end{array}$ & $\begin{array}{c}\text { Standard } \\
\text { Deviation } \\
(\text { STDEV })\end{array}$ & $\begin{array}{c}\text { Standard } \\
\text { Error } \\
(\text { STERR })\end{array}$ & $\begin{array}{c}\text { T Statistics } \\
(\mid \text { OSTERR } \mid)\end{array}$ \\
\hline $\begin{array}{l}\text { E-Satisfaction } \rightarrow \text { E-Loyalty } \\
\begin{array}{l}\text { E-Service Quality } \rightarrow \text { E- } \\
\text { Satisfaction }\end{array}\end{array}$ & 0,680552 & 0,683409 & 0,078724 & 0,078724 & 8,644749 \\
$\begin{array}{l}\text { E-Service Quality } \rightarrow \text { Overall } \\
\text { E-Service Quality } \\
\begin{array}{l}\text { Overall E-Service Quality } \rightarrow E- \\
\text { Loyalty }\end{array}\end{array}$ & 0,555227 & 0,561848 & 0,067185 & 0,067185 & 8,264168 \\
$\begin{array}{l}\text { Overall E-Service Quality } \rightarrow E- \\
\text { Satisfaction }\end{array}$ & 0,176015 & 0,172768 & 0,086568 & 0,086568 & 2,033248 \\
\hline Sum & 0,379038 & 0,372395 & 0,072737 & 0,072737 & 5,211043 \\
\hline
\end{tabular}

Sumber: Olahan Penulis, 2015

Tabel 13: Uji Signifikansi Directional

\begin{tabular}{lcc}
\hline & T-Statistic & T-Statistic Directional \\
\hline E-Satisfaction $\rightarrow$ E-Loyalty & 8,64475 & 4,322375 \\
E-Service Quality $\rightarrow$ E-Satisfaction & 8,26417 & 4,132084 \\
E-Service Quality $\rightarrow$ Overall E-Service Quality & 55,7773 & 27,88866 \\
Overall E-Service Quality $\rightarrow$ E-Loyalty & 2,03325 & 1,016624 \\
Overall E-Service Quality $\rightarrow$ E-Satisfaction & 5,21104 & 2,605522 \\
\hline
\end{tabular}

Sumber: Olahan Penulis, 2015

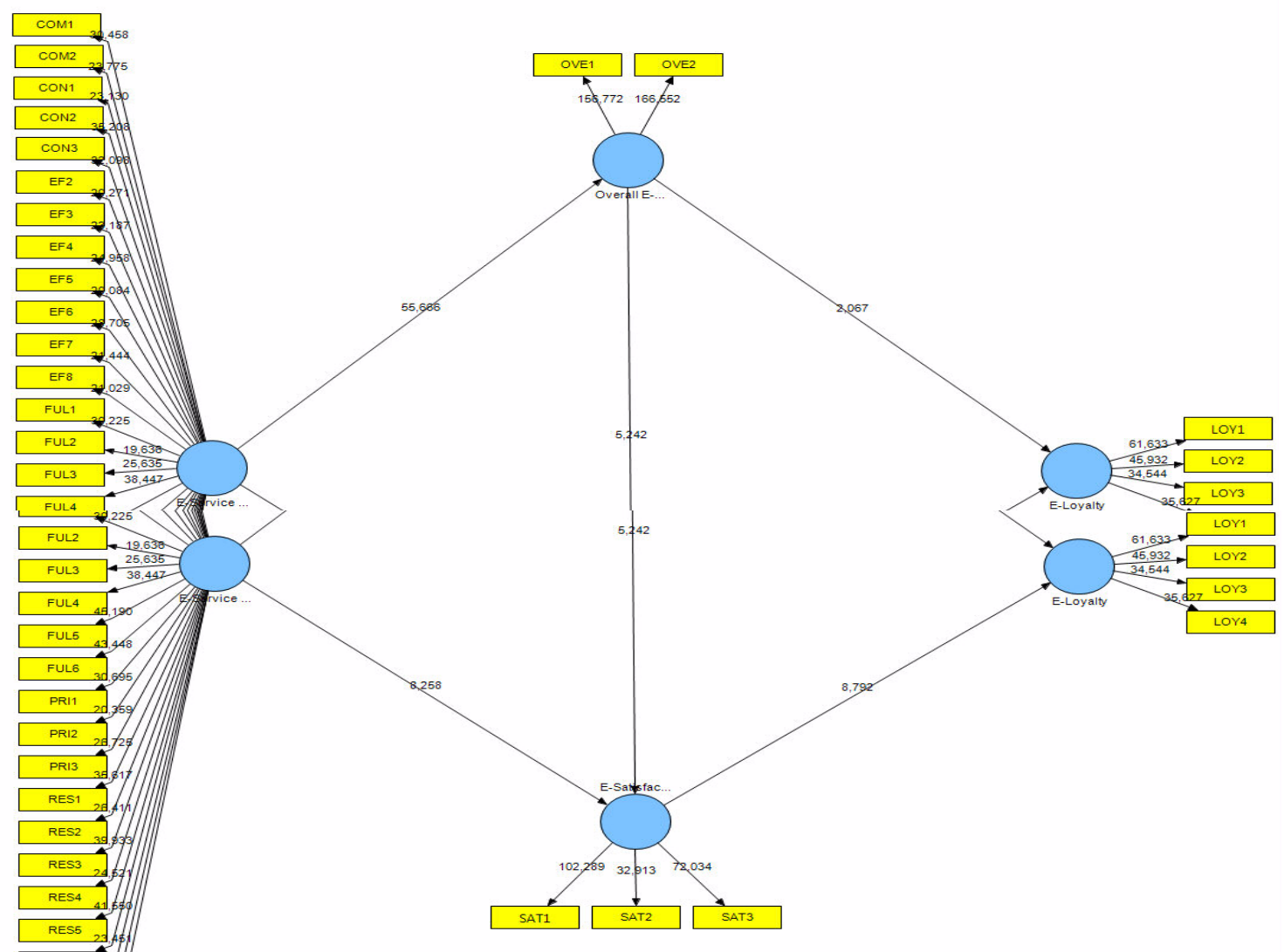

Gambar 3: Bootstrapping

Sumber: Olahan Penulis, 2015 
Uji Signifikansi menjelaskan apakah terdapat pengaruh di antara variabel yang diteliti. Menggunakan tingkat error 0,5\% dengan kriteria minimum pada $t$-statistic sebesar 1,96 , jika nilai angka lebih besar dari 1,96 maka $H_{0}$ ditolak dan apabila nilai kurang dari 1,96 maka $H_{0}$ diterima. Suharyadi dan Purwanto (2004, p.396) mengatakan, karena area pengujian direksional mempunyai dua daerah, maka masing - masing daerah dilambangkan dengan $1 / 2 \alpha$. Dari uji signifikansi 1 arah yang telah di lakukan, maka hasil dari T-Statistic harus di bagi 2 dimana menghasilkan data sebagaimana tampak pada tabel 12 .

Hasil dari pengujian dengan bootstrapping dari analisis PLS adalah sebagai berikut:

Pada variable hasil Output dari $T$ Statistic pada tabel 13 menunjukan variabel overall e-service quality, E-Service Quality berpengaruh signifikan positif terhadap variabel overall e-service quality, karena nilai $t$ statistic mencapai 27,88866 dimana berada > 1,96 sehingga $H a$ diterima.

Untuk variable e-Satisfaction, hasil Output dari T-Statistic pada tabel 13 menunjukan variabel E-Service Quality berpengaruh signifikan positif terhadap variabel $e$-Satisfaction karena nilai $t$-statistic mencapai 4,132084 dimana berada > 1,96 sehingga $\mathrm{Ha}$ diterima.

Hasil Output dari T-Statistic pada tabel 13 menunjukan variabel overall e-service quality berpengaruh signifikan positif terhadap variabel e-satisfaction, karena nilai $t$-statistic mencapai 2,605522 dimana berada >1,96 sehingga $\mathrm{Ha}$ diterima.

Hasil Output dari T-Statistic pada tabel 13 menunjukan variabel overall e-service quality tidak berpengaruh signifikan positif terhadap variabel $e$-loyalty, karena nilai $t$ statistic mencapai 1,016624 dimana berada < 1,96 sehingga $\mathrm{Ha}$ ditolak.

Hasil Output dari T-Statistic pada tabel 13 menunjukan variabel e-Satisfaction berpengaruh signifikan positif terhadap variabel $e$ loyalty, karena nilai t-statistic mencapai 4,322375 dimana berada > 1,96 sehingga $\mathrm{Ha}$ diterima.

\section{PENUTUP}

\section{Kesimpulan}

Berdasarkan hasil analisa data yang dilakukan peneliti, dalam situs Bhinneka.com maka pene- litian ini menunjukkan hasil bahwa e-servicequality dan overall e-service quality memiliki pengaruh pada e-satisfaction. Sedangkan $e$ satisfaction menjadi variable penting dalam mempengaruhi e-loyalty.

\section{Keterbatasan dan Saran Penelitian}

Peneneltian ini masih terbatas pada satu jenis situs belanja saja, oleh karena itu penulis memberikan beberapa masukan bagi penelitian berikutnya sebagai berikut: 1) Penelitian ini hanya membahas pada bidang website e-commerce $b 2 c$ di Indonesia yaitu Bhinneka.com. Penelitian selanjutnya diharapkan meneliti di bidang lain seperti onlinebanking, onlinegames atau lainnya yang masih berkaitan dengan website. Penelitian selanjutnya juga bisa menambah variabel lain yang berpeluang dalam mempengaruhi loyalitas seperti Trust, E-WOM, dan lain - lain. 2) Responden dalam penelitian tidak dibagi berdasarkan demografi wilayah. Peneliti hanya ingin mengetahui tingkat loyalitas konsumen tanpa memandang karakteristik dan latar belakang konsumen. Oleh karena itu dalam penelitian selanjutnya, diharapkan bisa membagi demografi konsumen secara lebih lengkap dan mendetail. Juga bisa melakukan pembagian berdasarkan tingkat pendapatan konsumen. 3) Dikarenakan pengujian hanya menggunakan metode PLS yang mana mempunyai keunggulan dan kelemahan tersendiri, disarankan pada penelitian selanjutnya untuk menggunakan metode lain agar bisa dikomparasi akan hasil penelitian yang akurat dan maksimal. 4) Penelitian yang dilakukan kali ini pada website Bhinneka.com bersifat cross section yang dilakukan hanya pada satu waktu tertentu, yang mana diketahui bersama bahwa perilaku konsumen adalah sesuatu yang berubah - ubah seiring berjalannya waktu. Oleh karena itu sebaiknya pada penelitian selanjutnya menggunakan longitudinal research untuk mengetahui hasil penelitian secara konsisten dari waktu ke waktu.

\section{DAFTAR PUSTAKA}

Abels, E. G., White, M. D., dan Hahn, K. 1998. A user-based design process for Web sites. Internet Research: Electronic Networking Applications and Policy. 39-48. 
Afsar, A., Nasiri, Z., dan Zadeh, M. O. 2013. E loyalty Model in e-Commerce. Mediterranean Journal of Social Science. 4(9).

Alexa.com. (n.d.). Bhinneka.com. Alexa.com: http://www.alexa.com/siteinfo/bhinnek a.com. Diakses tanggal 18 Maret 2015.

At Hawari, M. A. 2014. Does customer sociability matter? Differences in equality, e-satisfaction, and e-loyalty between introvert and extravert online banking users. Journal of Services Marketing. 538-546.

Anderson, R.E. dan Srivinasan, S.S. 2003. ESatisfaction and E-loyalty: A Contingency Framework. Journal of Pshycology \& Marketing. 20(2). 123- 138.

APJII, A. P. 2012. Profil Pengguna Internet Indonesia.

Ariff, M. S. M., Yun, L. O., Zakuan, N., dan Ismail, K. 2013. The impacts of service quality and customer satisfaction on customer loyalty in internet banking. World Congress on Administrative and Political Sciences. 81. 469-473.

Asgari, A. A., Hamid, A. B. A., Asgari, A., dan Mousavipour, S. 2012. The Determinants of E-Relationship Quality on E-Satisfaction In Hotel Websites.IOSR Journal of Engineering.2(9).36-41.

Bastos, J A.R., and Gallego, P.M. 2008. Pharmacies Customer Satisfaction and Loyalty: A Framework Analysis. Journal of Marketing. Universidad de Salamanca.

Bhinneka.com. 2014. Bhinneka.com. facebook.com:

https://www.facebook.com/notes/bhinn ekacom/sejarah-terbentuknyabhinnekacom/803176383029848 Diakses tanggal 12 Maret 2015

Bloemer, J. 1998. Investigating Derivers of Bank Loyalty: The Complex Relationship Between Image, Service Quality and Satisfaction. International Journal of Bank Marketing.16,(7). 276- 286.

Bloemer, J. M. M., dan Kasper, H. D. P. 1995. The complex relationship between consumer satisfaction and brand loyalty. Journal of Economic Psychology.16.311-329.

Budiaji, W. (2013). Skala pengukuran dan jumlah respon skala likert. Jurnal Ilmu Pertanian dan Perikanan. 125-131.

Carlson, J. dan O'Cass. 2011. Developing a framework for understanding e-service quality, its antecedents, consequences and mediators. Managing Service Quality: An International Journal. 21(3). 264-286.

Carlson, J., dan O'Cass, A. 2010. Exploring the relationships between e-service quality, satisfaction, attitudes and behaviours in content-driven e-service web sites. Journal of Service Marketing, 112-127.

Caruana, A. 2002. Service loyalty: The effects of service quality and mediating role of customer satisfaction. European Jounal of Marketing.36(7).811-828.

Chaffey, D., Ellis-Chadwick, F., Mayer, R., dan Johnston, K. 2009. Internet Marketing: Strategy, Implementation, and Practice. Italy: Pearson Education Limited.

Chen, M.-H., Tsai, K.-M, Hsu, Y.-C, dan Lee, K.-Y. 2013. E-service quality impact on online customer's perceived value and loyalty. China- USA Business Review.12(5). 473-485.

Chu, P.-Y., Lee, G.-Y., dan Chao, Y. 2012. Service quality, customer satisfaction, customer trust, and loyalty in an eBanking context. Socail Behavior and Personality. 1271-1284.

Chung, Ki-Han dan Shin, Jae-Ik. 2008. The relationship among e-retailing attributes, e-satisfaction and e-loyalty. Management Review: An International Journal. 3(1).

Cristobal, E., Flavian, C., dan Guinalu, M. 2007. Perceived e-service quality (PeSQ). Managing Service Quality: An International Journal. 17(3).317-340.

Cyr, D. 2008. Modeling website design across culture: relationship to trust, satisfaction and e-Loyalty. Journal of 
Management Information System. 24(4). 47-72.

Dick, A.S dan Basu, K., 1994, Customer loyalty: Toward an ntegrated conceptual framework, Journal of The Academy Marketing Science. 22. 99-113.

Eid, M. I. (2011). Determinants of e-commerce customer satisfaction, trust, and loyalty in Saudi Arabia. Journal of Electronic Commerce Research. 78-93.

Flavian, C., Guinaliu, M., dan Gurrea, R. 2006. The role played by perceived usability, satisfaction and consumer trust on website loyalty. Information and Management. 43(1). 1- 14.

Ghane, S., Fathian, M., dan Gholamian, M. 2011. Full relationship among esatisfaction, e-trust, e-service quality, and e-loyalty: The Case of Iran EBanking. Journal of Theoritical and Applied Information Technology. 3(1).

Ghozali, I., dan Latan, H. 2012. Partial Least Square: Konsep, Teknik, dan Apilikasi Menggunakan Program SmartPLS 2.0 M3. Semarang: Badan Penerbit Universitas Diponegoro.

Gommans, M., Krishnan, K.S., dan Scheffold, K. B. 2001. From brand loyalty to eloyalty: a conceptual framework. Journal of Economic and Social Research. 3(1). 43-58.

Gounaris, S., Dimitriadis, S., dan Sthathakopoulos, V. 2010. An examination of the effects of service quality and satisfaction on customers' behavioral intentions in e-shopping. Journal of Service Marketing. 24(2), 142-156.

Jahanshahi, A. A. 2011. Study the effects of customer service and product quality on customer satisfaction and loyalty. International Journal of Humanities and Social Science. 1(7).253.

Jin, B., Park, J. Y., dan Kim, J. 2008. Crosscultural examination of the relationships among firm reputation, esatisfaction, e-trust, and e-loyalty. International Marketing Review. 324337.
Kheng, L.L, Mahammad, O., Ramayah, T., dan Mosahab, R. 2010. The impact of service quality on customer loyalty: a study of banks in Penang, Malaysia. International Journal of Marketing Studies.2(2).57-66.

Kim, J.-H., dan Kim, C. 2010. E-service quality erceptions: a cross-cultural comparison of American and Korean consumers. Journal of Research in Interactive Marketing. 4(3).257-275.

Kumar V. dan Shah D. 2004. Building and sustaining profitable customer loyalty for the 21 st century. Journal of Retailing.80.317-330.

Lee, G.-G.,dan Lin, H.-F. 2005. Customer perceptions of e-service quality in online shopping. International Journal of Retail dan Distribution Management.161-176.

Malhotra, N. K. 2012. Basic Marketing Research Intregation of Social Media 4th Edition. USA. Pearson Education Inc, Prentice Hall.

Mittal, A. 2013. E-commerce: it's impact on consumer behavior. Global Journal of Management and Business Studies.3(2).131-138.

Mosahab, R., Mahamad, O., dan Ramayah, T. 2010. Service quality, customer satisfaction and loyalty: a test of mediation. International Business Research.3(4).

Oliver, R.L., 1999. Whence consumer loyalty. Journal of Marketing. 63. 33-44a.

Parasuraman, A., Zeithaml, V. A., dan Berry, L. L. 1985. A conceptual model of service quality and its implications for future research. Journal of Marketing. 49. 41-50.

Parasuraman, A., Zeithaml, V. A., dan Berry, L. L. 1988. SERVQUAL: A multiple item scale for measuring consumer perceptions of service quality. Journal of Retailing.12-40.

Parasuraman, A., Zeithaml, V. A., dan Malhotra, A. 2005. E-S-Qual: a multiple item scale for assessing electronic 
service quality. Journal of Service Research. 213-233.

Peter, J. P., dan Olson, J. C. 2010. Consumer Behavior \& Marketing Strategy, Ninth Edition. New York, America. McGraw Hill.

Rachjaibun, N. 2007. A Study of Antecedents of e-Relationship Quality in Hotel Website. Master of Thesis

Ribbink, D., Riel, A. C. R., Liljander, V., dan Streukens, S. 2004. Comfort your online customer quality, trust and loyalty on the internet. Managing Service Quality: An International Journal. 4(6). 446-456.

Rolland, S., dan Freeman, I. 2010. A new measure of e-service quality in France. International Journal of Retail \& Distribution Management. 497-517.

Salomon, M. R. 2011. Consumer Behavior, Buying, Having, and Being, ninth edition. New Jersey: Pearson Education Inc.

Sanayei, A., \& Jokar, A. 2013. Determining the Effect of Electronic Services Quality on Electronic Satisfaction and Positive Word of Mouth (Case Study: Different Branches of Shiraz Mellat Bank Customers. International Journal of Academic Research in Accounting, Finance and Management Sciences, 103-111.

Santos, J. 2003. E-service quality: a model of virtual service quality dimensions. Managing Service Quality, 233-246.

Seiler, V. L., Seiler, M. J., Arndt, A. D., Newell, G., \& Webb, J. R. 2010. Measuring Service Quality with Instrument Variation in an SEM Framework. Journal of Housing Researc, 47-63.

Sekar, P. 2014. Pemasar Perlu Tahu 4 Fakta Tentang Perilaku Konsumen Online. Retrieved Maret 7, 2015, from http://www.marketing.co.id/pemasarperlu-tahu-4-fakta-tentang-perilakukonsumen-online/

Sekaran, U. 2011. Research Methods for Business Edisi 4. Jakarta: Salemba Empat.
Sekaran, U., \& Bougie, R. 2013. Research Methods for Business: A Skill-Building Approach 6th Edition. New Jersey: John Wiley \& Sons Ltd.

Seth, N. \& Deshmukh, S.G. 2005. Service quality model: a review. International Journal of Quality \& Reliability Management. 22(9), 913-949.

Shankar, V., Smith, A.K., \& Rangaswamy, A. 2003. Customer satisfaction and loyalty in online and offline environment. International Journal Research in Marketing, 20(2), 153-175.

Shu-Chiung, L., Sheng-Wei, L., Chin-Yen, T., Ying-Ping, Y., \& Pei-Hwa, Y. 2011. How E-SERVQUAL affects customer's online purchase intention through cross-culture comparison. Proceedings of the Technology Innovation and Industrial Management, 1-13 .

Srinivasan, S.S., Anderson, R., dan Ponnavolu. 2002. Customer Loyalty in ECommerce: An Exploration of Its Antecedents and Consequences. Journal of Retailing, 78, 41-50.

Status, I. W. 2014. Retrieved Maret 6, 2015, from http://internetworldstats.com/stats3.ht $\mathrm{m}$

Sugiyono. 2014. Metode Penelitian Manajemen. Bandung: Alfabeta.

Suharsaputra, U. (2012. Metode Penelitian: Kuantitatif, Kualitatif, dan Tindakan. Bandung: Refika Aditama.

Suharyadi, \& Purwanto, S. 2004. Statistika Untuk Ekonomi \& Keuangan Modern. Jakarta: Salemba Empat.

Supranto, J., \& Limakrisna, N. 2009. Penelitian Ilmiah untuk Menyusun Skripsi, Tesis, dan Disertasi. Jakarta: Mitra Wacana Media.

Szymanski, D. M., \& Hise, R.T. 2000. Esatisfaction: an initial examination. Journal of Retailing. 76(3), 309-322.

Walker, O. C., Mullins, J. W., \& Larreche, J.C. 2008. Marketing Strategy: A Deci- 
sion-Focused Approach. Singapore: McGraw Hill International Edition.

Yang, Z., \& Peterson, R.T. 2004. Customer perceived value, satisfaction, and loyalty: The role of switching costs. Psychology \& Marketing, 21(10), 799822.

Yang, Z., Jun, M., \& Peterson, R. T. 2004. Measuring customer perceived online service quality: Scale development and managerial implications. International
Journal of Operations \& Production Management, 1149-1174.

Yi, Y. 1990. A critical review of consumer satisfaction, in Zeithaml, V. (Ed.), Review of Marketing, 1990, American Marketing Association, Chicago, IL, 68-123.

Zeithaml, V. A., Bitner, M. J., \& Gremler, D. D. 2013. Services Marketing - Integrating Customer Focus Across the Firm. Singapore: McGraw-Hill International Edition. 